\title{
Science Teaching Experiences in Informal Settings: One Way to Enrich the Preparation Program for Preservice Science Teachers
}

\author{
Pei-Ling Hsu \\ Department of Teacher Education, College of Education, University of Texas at El Paso, USA
}

Copyright $(2016$ by authors, all rights reserved. Authors agree that this article remains permanently open access under the terms of the Creative Commons Attribution License 4.0 International License

\begin{abstract}
The high attrition rate of new science teachers demonstrates the urgent need to incorporate effective practices in teacher preparation programs to better equip preservice science teachers. The purpose of the study is to demonstrate a way to enrich preservice science teachers' preparation by incorporating informal science teaching practice into science method courses. A phenomenographic study was conducted to understand preservice teachers' experiences in informal science practice and discuss the multiple benefits of this practice. Five experiential descriptions are identified: (a) rigorous preparations to teach in an informal environment; (b) an engaging and informative environment for teaching and learning; (c) improvisation to address learners' needs spontaneously; (d) a sense of contribution and rewarding experience; and (e) insight development for teaching through feedback, reflection, and observation. These experiences allow preservice teachers to develop confidence in science teaching that may help them overcome obstacles when they become science teachers.
\end{abstract}

Keywords Informal Science Teaching, Preservice Teachers, Phenomenography, Teacher Education

\section{Introduction}

Novice teachers often encounter trials and setbacks during their first year of teaching. They are challenged every day and face uncertainty about whether their students are benefiting from their teaching [7]. Many novice teachers find themselves overwhelmed by the responsibilities given to them, and they find themselves 'learning by doing' [10]. The top five challenges novice teachers encounter are emotionally disturbed students, students with psychological disorders, overactive children, special education students in general education classrooms, and stress management [5]. Four of the five challenges have to do with the student demographic found in the classroom. Since preservice teachers usually do not spend much time interacting with students prior to becoming a full-time teacher, many novice teachers find working with challenging students difficult [26]. Research shows that, as a result of these difficulties, 20 to 25 percent of novice teachers of mathematics, science, and special education leave the profession during their first three years after graduation from a preservice program $[7,12,17$, 27]. This high attrition rate is common in North America. It is essential that educators improve teacher education programs to provide preservice teachers with appropriate knowledge, skills, dispositions, attitudes, etc., in order that they are better equipped to handle the challenges they will encounter when they graduate from their teacher education program. However, many courses in teacher education programs for preservice teachers, including both content and method courses, draw on traditional and lecture-based approaches. For the subject of science in particular, research has shown that the more hours of traditional science courses students take, the more negative their attitudes toward science [24]. In a study of 52 preservice teachers, about 60 percent of the teachers felt that their subject matter knowledge was weak [19]. Insufficient knowledge about the content and disciplines of science, learners, instruction, learning environments, and professionalism are five major challenges encountered by preservice teachers [8]. As a result of encountering challenges, many preservice teachers have expressed that they felt their university education had not prepared them to teach science in schools [15].

To achieve a systemic change in teacher education with the goal of preparing teachers to address these challenges, we need to transform the ways that preservice teachers are prepared and educated. One suggestion generated from research results is to incorporate informal science education as part of preservice teachers' training programs. Informal science education contains various forms of out-of-school learning that are often socially constructed, self-motivated, voluntary, and guided by learners' needs and interests [2003]. These unique features of informal science education provide a nonthreatening and supportive environment that offers 
numerous benefits for science teacher preparation programs, including (a) improving preservice teachers' attitudes, interest, and curiosity in science $[6,9,20]$, (b) facilitating preservice teachers to learn constructivist-based teaching practice and transformative teaching strategies [2, 13, 23], (c) enhancing preservice teachers' identities as science teachers [14], and (d) developing contemporary ideas about science teaching and learning [3]. Until now, however, little research has used the phenomenographic approach to understand preservice teachers' teaching experience in informal settings. Therefore, the research question for this study is 'What are preservice teachers' salient experiences of teaching in informal settings?' That is, this study investigated preservice teachers' experiences of teaching in informal settings, and this article discusses how these unique experiences may help preservice teachers to reflect on their teaching practices through gaining real-life teaching experience prior to entering the formal setting of the classroom.

\section{Theoretical Framework: Phenomenography}

To identify different ways of experiencing a phenomenon, phenomenography was developed from an empirical educational framework by Ference Marton and his coworkers in the 1970s in Sweden. Phenomenography constitutes a second-order and nondualistic perspective to aim at description, analysis, and understanding of people's experiences [16]. The analysis is of the second-order type (statements-about-perceived-reality) in the sense that phenomenography focuses on describing people's experience of various aspects of the world rather than describing various aspects of the world (first-order perspective: statements-about-reality, e.g., ethnography). To use a second-order perspective, researchers investigate not only the world but people's perceptions of it. Researchers can thus provide a wider understanding of people's experiences and inform the pedagogical potentiality. Phenomenography is nondualistic in the sense that it understands that objects and subjects cannot be separated: the world is what we perceive and experience it to be. Phenomenographic studies focus neither on mental entities nor physical things, but on internal relationships between the subject and the world - intentionality. The basic analytic unit in phenomenography is "a way of experiencing something," which indicates an internal relationship between the experiencer and the experienced. For instance, when students are asked how the number 5 can be obtained, one might sense it as $3+2$, but another one may say $4+1$. Even though the numbers are the same, but the ways of sensing are different for different students. This sense is an internal relationship between the subject (student) and the object (numbers). Without one of them, this internal relationship would not exist. In phenomenography, an experiential conception is the unit of experiential description and has both a referential and a structural aspect [16]. The referential aspect refers to the global meaning of the object conceptualized and the structural aspect refers to the specific features that have been discerned and focused on within the conception. These two aspects intertwine to constitute a conception. The goal of phenomenography is to observe, analyze, and understand experiences [16] and to gather the different points of view and perceptions people have regarding certain events and experiences [22]. These results can then be translated into findings and categories based on the participants' perspectives. These categories are constructed according to the similarities and differences of the participants' responses. This particular study compared each preservice teacher's perspective and collected data on the patterns from the various preservice teachers' responses. The frequency of these responses was also collected to determine the participants' views on what was most critical and important to them.

\section{Research Context}

\section{Science Method Course Design: Incorporating Informal Science Teaching Practices}

This study was situated in two science method courses, having 38 preservice science teachers enrolled, in a south-central U.S. university. These preservice teachers were university junior or senior students and included 25 females and 13 males. The participants were Hispanic Americans, except for one African American. Most of them did not have any previous formal teaching experience except for occasional tutoring or teacher assistantships. These preservice teachers spent about 3 hours a week for 15 weeks in attending the science method courses. To help preservice teachers develop important teaching skills and knowledge, I designed an educational event called Science Circus Days, which serves as an important milestone in my undergraduate science method courses. A visual presentation of the course design is illustrated in Figure 1. Science Circus Days are public events that allow preservice teachers to teach their science lesson plans in an informal setting, such as a museum. At the beginning of each semester, I coordinate with local museums to set up dates to hold the event and then contact school principals and teachers to arrange field trips to bring their students to the museums to visit our Science Circus Days. During the science method courses, preservice teachers learn how to design lesson plans and provide constructive feedback to improve each other's lesson plans. Their lesson plans are practiced, reviewed, and discussed by the instructor and the whole class during a 'Virtual Science Circus Day' as a rehearsal to improve and modify the lesson plans. During Science Circus Days, the preservice teachers implement the lesson plans they prepared in the science method course. They bring materials (e.g., posters, samples, materials for hands-on activities) to engage all ages of visitors, including $\mathrm{K}-12$ students, preschool children, 
parents, families, teachers, and others. Each science method course holds two Science Circus Days, one in the middle of a semester and the other at the end. The second opportunity allows students to reflect on their previous teaching practice in the first Science Circus Day and implement ideas for improvement in the second event. Each Science Circus Day lasts for about two hours and is full of joy and excitement because of the fun learning environment and hands-on activities. Snapshots of the Science Circus Days can be found in Figure 2.

\section{The Visual Representation of the Course Design}

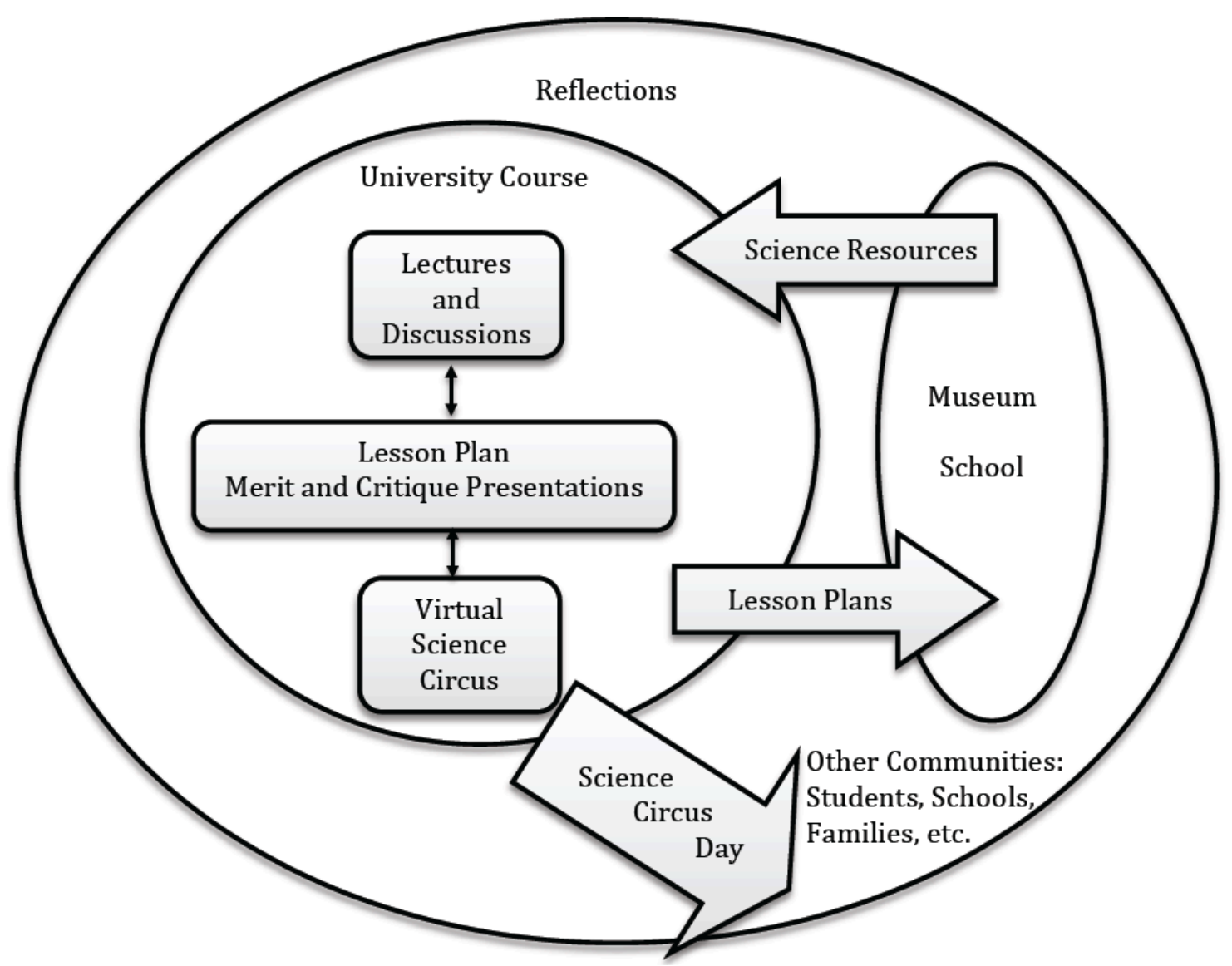

Figure 1. Visual presentation of the course design for the science method courses.
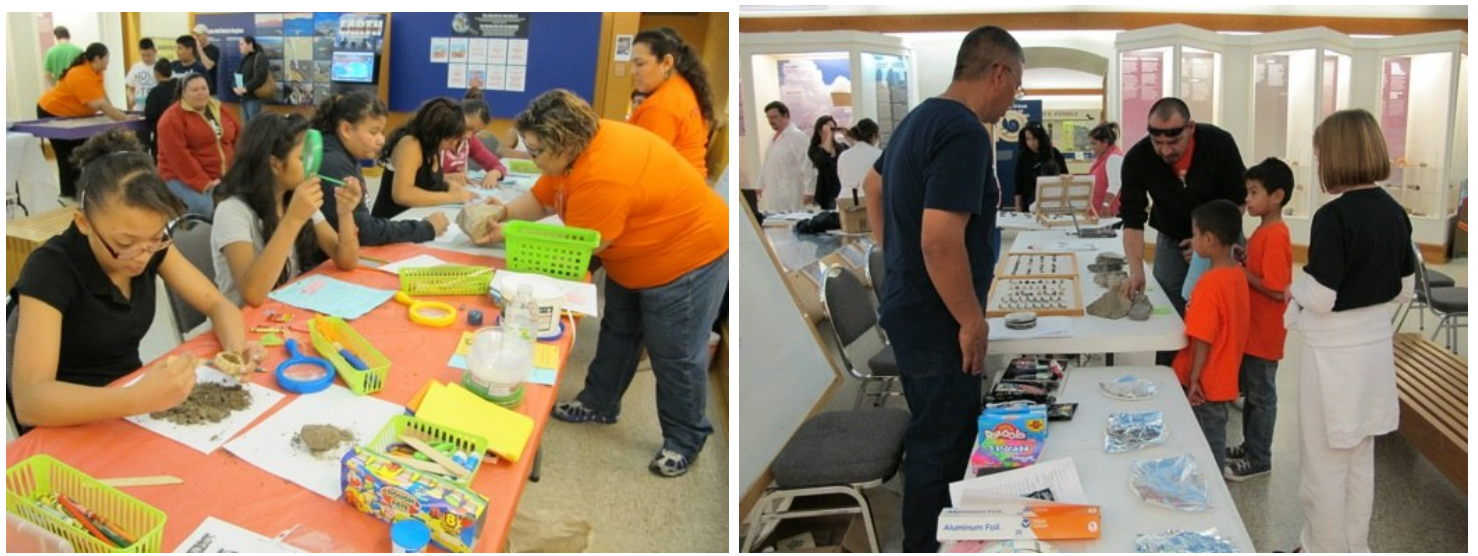

Figure 2. Snapshots of Science Circus Days. 


\section{Data Sources and Methods}

To identify different experiences of informal science teaching practices, I use phenomenography [16] as a method to analyze preservice teachers' experience. The goal of phenomenography is to observe, analyze, and understand experiences and to gather the different viewpoints and perceptions people have regarding certain events and experiences [22]. These results can then be translated into findings and categories based on the participants' perspectives. These categories are constructed according to the similarities and differences of the participants' responses. This particular study compared each preservice teacher's perspective and collected data on the patterns within the various preservice teachers' responses. The frequency of the responses was also collected to determine the participants' views on what was important and most critical to them. Twenty-one preservice teachers (out of 38 preservice teachers) volunteered to participate in this study. Their reflections on Science Circus Days were collected through their writing and individual interviews. During the open-ended interviews, they were invited to write key words regarding their experiences on sticky notes and to explain these notes thoroughly during the interviews. Each interview lasted for 40 to 60 minutes. These interviews were transcribed verbatim and analyzed to identify salient experiences shared among the preservice teachers.

\section{Data Analysis}

For the data analysis to identify participants' salient experiences, the following procedrures were implemented [16] to discern participants' different ways of experiencing Science Circus Days: (a) familiarization (we repeatedly read transcripts and watched videos); (b) condensation (we identified key answers expressed by participants); (c) classification (we grouped similar features within or between participants); (d) preliminary comparison (we established borders of initial categories); (e) naming (we gave essential names to each category); (f) contrastive comparison (we described unique characteristics in each category, their resemblances, and relationships between categories). Three techniques were also considered to assess the significant elements in participants' descriptions [22]: frequency (how often a meaningful statement is articulated); position (very often the most significant elements are found in the beginning stage of answers); and pregnancy (when participants emphasize certain aspects more than others, such as through the key words on cards, or through gestures or intonations captured by the videos). These techniques allow researchers to identify participants' salient experiences expressed during interviews [11]. To establish the validity of the data analysis, three criteria introduced to justify the basic quality of phenomenographic studies were also used [16]: (a) each category of description should be distinct from each other and stand in clear relation to the phenomenon; (b) these categories of description should stand in a logical relationship with one another; (c) the system should be parsimonious to capture critical variations in the data.

\section{Experiential Descriptions of Science Teaching in Informal Settings}

The phenomenographic analysis identified five categories of experiential description: a) rigorous preparations to teach in an informal environment; (b) an engaging and informative environment for teaching and learning; (c) improvisation to address learners' needs spontaneously; (d) a sense of contribution and rewarding experience; and (e) insight development for teaching through feedback, reflection, and observation. A summary of the referential and structural aspects of experiential descriptions is illustrated in Table 1. The meanings of each category are discussed in the following sections.

Table 1. Referential and structural aspects of experiential descriptions about science teaching in informal settings.

\begin{tabular}{|c|c|c|c|}
\hline Category of description & Referential Aspect & \multicolumn{2}{|c|}{ Structural Aspect } \\
\cline { 3 - 4 } & Focus & Dimension \\
\hline $\begin{array}{c}\text { A. Rigorous preparations to teach } \\
\text { in an informal environment }\end{array}$ & $\begin{array}{c}\text { Capture the attention of } \\
\text { audience }\end{array}$ & $\begin{array}{c}\text { Preparation and organization } \\
\text { instructions, handouts, methods, } \\
\text { knowledge }\end{array}$ \\
\hline $\begin{array}{c}\text { B. An engaging and informative } \\
\text { environment for teaching and } \\
\text { learning }\end{array}$ & $\begin{array}{c}\text { Provide an informative and } \\
\text { positive learning experience }\end{array}$ & $\begin{array}{c}\text { Rich, student-centered learning } \\
\text { environment }\end{array}$ & $\begin{array}{c}\text { Rich artifacts, displays, hands-on } \\
\text { activities, free movement space }\end{array}$ \\
\hline $\begin{array}{c}\text { C. Improvisation to address } \\
\text { learners' needs spontaneously }\end{array}$ & $\begin{array}{c}\text { Address learners' needs and } \\
\text { background }\end{array}$ & $\begin{array}{c}\text { Differences among learners and } \\
\text { teaching modifications }\end{array}$ & $\begin{array}{c}\text { Learners' interests, ages, } \\
\text { background knowledge, learning } \\
\text { styles }\end{array}$ \\
\hline $\begin{array}{c}\text { D. A sense of contribution and } \\
\text { rewarding experience }\end{array}$ & $\begin{array}{c}\text { Contribute to the local } \\
\text { community }\end{array}$ & $\begin{array}{c}\text { Learners' learning outcomes and } \\
\text { feedback }\end{array}$ & $\begin{array}{c}\text { Teaching skills, engagements, } \\
\text { assessment results, comments }\end{array}$ \\
\hline $\begin{array}{c}\text { E. Insight development for } \\
\text { teaching through feedback, } \\
\text { reflection, and observation }\end{array}$ & $\begin{array}{c}\text { Gain insights into teaching } \\
\text { strategies, quality, and practice }\end{array}$ & $\begin{array}{c}\text { Strengths and weakness of } \\
\text { self-teaching }\end{array}$ & $\begin{array}{c}\text { Knowledge, instructions, methods, } \\
\text { interactions, materials, informal } \\
\text { science education }\end{array}$ \\
\hline
\end{tabular}




\section{Rigorous Preparations to Teach in an Informal Environment}

One common experiential description of Science Circus Days was rigorous preparations to teach in an informal environment (shared by 18 of 21 students [86\%]). A significant feature of informal settings like museums is the unpredictable nature of the environment. For example, the number and nature of visitors cannot be predicted because Science Circus Days are public events that invite a variety of people (e.g., families, friends, students) whose backgrounds might be varied and diverse. Meanwhile, since museums are not places that preservice teachers have total control over, it is not guaranteed that activities will be implemented as intended. Moreover, during the two hours of the Science Circus Day, the preservice teachers only have a short period of time in which to interact with certain audiences. Thus, the unpredictable and fast-paced nature of the informal setting provides a challenge for the preservice teachers in terms of preparing and planning the lessons. These challenges motivate the preservice teachers to conduct rigorous research on topics and spend extra effort and time in preparing their lesson plans for Science Circus Days. Examples of this experience are illustrated in Table 2.

\section{An Engaging and Informative Environment for Teaching and Learning}

Science Circus Days were experienced as an engaging and informative environment for teaching and learning (shared by 16 of 21 students [76\%]). An informal setting such as a museum is full of interesting and informative displays and exhibitions. For example, Insights Museum has a Tesla coil that can demonstrate electricity visually and Centennial Museum has authentic fossils, rocks, and other specimens. For Science Circus Days, preservice teachers created museum-relevant lesson plans and brought numerous materials to the museum to assist their teaching (e.g., models, posters, handouts). For example, each museum has rich artifacts and displays that allow preservice teachers to create engaging activities for students, such as a scavenger hunt in which students were invited to look closely at the museum artifacts as they searched for specific items as part of the learning process. The unique setting and artifacts naturally engaged both teachers and students and served as an exciting and rich environment for teaching and learning. Examples of this experience are illustrated in Table 3.

Table 2. Examples of participants' experiential descriptions regarding 'rigorous preparations to teach in an informal environment.'

\begin{tabular}{l} 
Experience A: Rigorous Preparations to Teach in An Informal Environment \\
\hline - 'The Science Circus Day seems to be more complex since no specific audience was expected and I had to manage adequate teaching \\
techniques for all audiences to be able to understand the material being covered.' \\
'Science Circus Day to me means gaining an experience in teaching at a very fast pace. It meant I had to know my lesson by heart.' \\
'It is also important to be organized and have everything that is needed at hand to avoid losing people's interest and letting them become \\
distracted.' \\
'I also learned to be prepared for the unexpected. The group was prepared with extra extension cords in case the laptops ran out of battery \\
and the plugs weren't close to the exhibit.' \\
'Not only academically I would think that the [Science] Circus Day was successful, but because I personally had a lot of fun creating the \\
lesson and the whole presentation. I was able to overcome many obstacles throughout creating the lesson.' \\
'The Science Circus Day reinforced for me the importance of being organized and prepared with all the necessary materials. As a future \\
middle school teacher, I need to remember to always rehearse and try out beforehand the materials and activities that I am going to present \\
to my future students to prevent frustration and lack of interest.'
\end{tabular}

Table 3. Examples of participants' experiential descriptions regarding 'an engaging and informative environment for teaching and learning.'

\begin{tabular}{l} 
Experience B: An Engaging and Informative Environment for Teaching and Learning \\
\hline$-\quad$ 'In the Centennial Museum, there were a lot of interesting artifacts and both adults and children were able to enjoy everything.' \\
'The Centennial Museum is full of some great exhibits. Having the opportunity to throw a Science Circus Day and be a part of it not only \\
allowed the visitors to view the exhibits but also learn one on one with our projects.' \\
'It is a great way to interact with the kids and have them learn about science in a fun learning environment. Here students are able to move \\
around, have hands-on activities, and also have more than one teacher there for them to answer their questions that the kids may have.' \\
'The Science Circus Day meant a day that family can unite and have fun while exploring and learning new topics.' \\
'When I look back at the Science Circus Day I immediately think of all the bright eyes that opened up when they started learning something \\
new.' \\
'The Science Circus Day experience gave me another opportunity to see in students the natural curiosity that they have and their innate \\
desire to learn and explore.'
\end{tabular}




\section{Improvisation to Address Students' Needs Spontaneously}

Another common experiential description of Science Circus Day was improvisation to address students' needs spontaneously (shared by 16 of 21 students [76\%]). Before the Science Circus Day, we distributed flyers to invite $\mathrm{K}-12$ students, their friends and families, and the public to attend. Thus, the visitors to Science Circus Day might include all ages of learners, including $\mathrm{K}-12$ students, preschool children, parents, teachers, and other adults. Because we were inviting diverse learners, the preservice teachers felt that it was very important for them to be able to improvise their teaching right there on the spot. For example, the preservice teachers needed to come up with different approaches to teach a third grader and an adult learner, and to modify their approaches when they encountered gifted and special need students. Moreover, in an informal setting such as a museum, where visitors are moving freely, the preservice teachers needed to grasp people's attention by modifying their approaches to address learners' needs because learners could choose to visit other stations. Thus, again, the diversity of the learners and the free-choice learning environment of the informal setting presented challenges to the preservice teachers to develop their capacity to improvise and modify their teaching. These challenges motivated the preservice teachers to be observant of and sensitive to different learners' needs and to do their best to modify their teaching according to different learning situations. Examples of this experience are illustrated in Table 4.

\section{A Sense of Contribution and Rewarding Experience}

During Science Circus Days, the preservice teachers felt a sense of contribution and rewarding experience (shared by 13 of 21 students [62\%]). The public event of Science Circus Days provided the preservice teachers with opportunities to really interact with the public by sharing scientific knowledge and activities. The instant feedback they received from visitors was an immediate benefit of the preservice teaching practice. The learning outcomes that happened as a result of Science Circus Days made the preservice teachers feel that they were contributing something useful to the visitors and making a difference in people's lives in the community. That is, Science Circus Days were meaningful events that allowed the preservice teachers to feel a sense of accomplishment and pride by offering their teaching practice to the community. Examples of this experience are illustrated in Table 5.

\section{Insight Development for Teaching through Feedback, Reflection, and Observation}

One common experiential description about Science Circus Days was developing insights for teaching through feedback, reflection, and observation (shared by 19 of 21 students [90\%]). While teaching at Science Circus Days, the preservice teachers reflected on their own teaching practices, realizing their strengths and weaknesses and identifying areas for improvement. Meanwhile, they closely observed others' teaching practices on the spot and learned from each other. Moreover, Science Circus Days helped the preservice teachers realize the importance of informal science education and inspired them to consider incorporating informal science into their future teaching. Examples of this experience are illustrated in Table 6.

Table 4. Examples of participants' experiential descriptions regarding 'improvisation to address students' needs spontaneously.'

\begin{tabular}{l} 
Experience C: Improvisation to Address Students' Needs Spontaneously \\
\hline 'Science Circus Day helped me be a better teacher by showing me how to handle lots of different learners at one time. It helped me realize I \\
- $h a v e$ to think on my feet. It taught me how to analyze each learner in a short period of time and take the lesson to their level.' \\
'I can tell many of the students that went to the Centennial Museum were visual, but others prefer to hear the information and then question \\
it. Mostly the youngest ones prefer to learn the information while they learn with the interactive concept map.' \\
'I learned in Science Circus Day that changes and modifications will always be necessary and this has to do with the fact that no two \\
students are alike. It is important to continuously and frequently evaluate your students to see whether they understand the content or \\
whether we need to backtrack and start over with a different approach.' \\
'Our lesson didn't go exactly as planned and that's where the modifications took place.' \\
'This is the second time experiencing teaching strangers. I was able to understand how to grasp the students' attention to want to learn. That \\
alone was the best experience I could have as a pre-teacher.' \\
'[Science Circus Day] taught me to be prepared to adapt. I think this is very useful, especially in a classroom, because lessons aren't always \\
going to go the way you planned.'
\end{tabular}

Table 5. Examples of participants' experiential descriptions regarding 'a sense of contribution and rewarding experience.'

\begin{tabular}{l} 
Experience D: A Sense of Contribution and Rewarding Experience \\
\hline - \\
'Being able to attend and be a part of activities like Science Circus Days in museums is very rewarding. I am able to learn many new things \\
- 'Science Circus Day has provided me with an opportunity to constructively obtain some of the experience I seek to become a better teacher. \\
This experience was very rewarding because it has helped me develop some of the teaching skills that I seek.' \\
'I felt great gratification to obtain positive feedback instantaneously.' \\
- 'I feel that our activities were the most successful and students seemed to be most engaged in them. It was a fulfilling moment for me.' \\
'A current UTEP [University of Texas at El Paso] student requested a copy of our lesson plan since she expected to one day integrate in her \\
- $\quad$ 'Oaching curriculum. Just to hear this was beyond excitement!' \\
'I must say I am privileged that I was able to reach out to my community and impart some of my knowledge and teaching skills to them.'
\end{tabular}


Table 6. Examples of participants' experiential descriptions regarding 'insight development for teaching through feedback, reflection, and observation.'

\begin{tabular}{|l|}
\hline Experience E: Insight development for teaching through feedback, reflection, and observation \\
\hline$-\quad$ 'It allowed me to channel my inner teacher and for once be seen as an authority rather than a small student.' \\
'I felt it did help me see my strengths and my weaknesses. I was able to see what needed improvement and what I felt I had mastered \\
already. It's something many students don't get the opportunity to do.' \\
'Science Circus Day also helped me become a better teacher because I was not only able to see my own group teach but also the other \\
groups teach as well. \\
'Science Circus Day to me is a once-in-a-lifetime experience that allows us to get a unique understanding of what good teaching should be. \\
It has made me aware of what we can do to make learning fun.' \\
Informal settings offer so much more to students than formal settings, like a classroom. Many teachers do not have the opportunities to see \\
that or ever experience these kinds of options.' \\
'I feel like I will carry this experience with me into my teaching career. I also learned the importance of integrating formal and informal \\
education. It is important to address the needs of every type of learner, and I feel like my knowledge of informal education has been greatly \\
increased. As a future teacher, I feel I now have the capacity to utilize a new tool in my teaching repertoire. Where I used to think museums \\
and field trips were not very useful, I now believe they are an integral part of education and should be implemented whenever possible.'
\end{tabular}

\section{Discussion and Conclusion}

Prior to internships or practicums, students at the university level do not typically get the opportunity to actually teach a self-created lesson to real students. They are usually prepared with theories, invited to observe other teachers, or given the opportunity to conduct 'mock teaching,' which allows them to teach lessons to their peers. Instead of mock teaching, preservice teachers in this study were provided with authentic teaching opportunities to teach real learners and receive real feedback. The study investigated preservice teachers' experiences of teaching in the informal setting of a museum. Five main salient experiences were shared by the preservice teachers: (a) rigorous preparations to teach in an informal environment; (b) an engaging and informative environment for teaching and learning; (c) improvisation to address learners' needs spontaneously; (d) a sense of contribution and rewarding experience; and (e) insight development for teaching through feedback, reflection, and observation.

Because of the unstructured, unpredictable, and unfamiliar nature of informal settings, the preservice teachers in this study spent extra effort and time conducting rigorous preparations to teach in an informal environment. They conducted in-depth research on their lesson plan topics, created materials and hands-on activities, discussed teaching plans repeatedly as a group, and rehearsed their teaching practice thoroughly. All of these preparations allowed the preservice teachers to be ready to teach all ages of learners and address diverse learners' needs. That is, teaching in an informal setting naturally motivated the preservice teachers to conduct rigorous preparations before implementing their lesson plans. This finding has important implications for science teacher education because one of the urgent issues in science education is that preservice teachers often do not acquire proficient science content knowledge before becoming full-time teachers [8]. That is, they went through two rigorous processes of preparing two solid lesson plans with appropriate materials and activities. Research shows that being able to seek specific resources to improve pedagogy is one of key competences that really help novice teachers succeed in their first few years of teaching [25]. These two cycles of teaching preparation and practice allowed the preservice teachers to experience what it is like to prepare a new lesson plan, from choosing a topic, finding appropriate resources, to implementing the lesson. As a result, if these preservice teachers need to teach a new lesson, they will already know how to prepare a lesson plan, seek resources and partnership, and create and integrate appropriate activities into it.

The rich resources and free movement space of informal settings constitutes an engaging and informative environment for teaching and learning. During Science Circus Days, preservice teachers were provided with the necessary creative outlet to engage learners in the science content and concepts being shown to them. A museum contains various forms of representation that usually are not available in the classroom. Different representations, when used effectively, are proven to help students develop a deeper cognitive understanding of science concepts. The representations in the museum, when paired with science lessons, create an effective form of informal science education (e.g., a scavenger hunt, which invites students to search and look closely at museum artifacts as part of the learning process). This study demonstrates the authenticity of museum science as a mechanism for teaching science and as a legitimate form of teaching practice. The experience of witnessing students' engagement, interest, and curiosity allowed the participating preservice teachers to appreciate the value of a fun learning environment and understand what good teaching practices look like. The study also has important implications for novice teachers who may enter schools where students normally do not enjoy science learning because of the numerous high-stakes tests that constrain teachers' instructional practices [4]. The enjoyment and student engagement of Science Circus Days may help novice teachers remember that science learning can be fun and may help them to create a stimulating environment to bring the joy of science learning back to students. In addition, being able to create a fun learning environment may mitigate the stress that novice teachers normally encounter in their first teaching year and increase their "impact power" [25] to influence student learning. They might have an easier time dealing with stress if they are confident that they can create a fun learning environment for students like the one the preservice teachers in this study 
created in Science Circus Days.

In this study, the unpredictable nature of the informal setting also provided unique practice for preservice teachers to be able to adapt and modify lessons. The preservice teachers realized that things do not always go as planned. During Science Circus Days, they were able to practice adapting and creatively modifying their lessons for diverse learners. For example, learners might sometimes struggle to understand concepts presented, technology glitches may occur, and other situations may arise to challenge novice teachers. Having an opportunity to experience dealing with such issues at Science Circus Days provided the preservice teachers with a more personal form of practice that is closely related to real-life experiences. The teaching experience gained in informal settings might also help novice teachers to deal effectively with the challenges they are likely to face in their first year of teaching, including emotionally disturbed students, students with psychological disorders, overactive children, special education students in general education classrooms, and stress management [5]. Four of these five challenges relate to student demographics. That is, the ability to modify teaching according to learners' diverse needs is an important skill, especially for novice teachers. In particular, preservice teachers usually 'do not have very clear ideas about what to do with regards to students' ideas or backgrounds' [8]. Through teaching in an informal setting, preservice teachers are given the opportunity to work with different types of students. Being able to observe and teach diverse learners prior to the first year of teaching can help alleviate the shock and nervousness that novice teachers feel when they first encounter students with different needs. Moreover, the repetitive teaching required in Science Circus Days also allowed the preservice teachers to learn in a short period of time how to modify their teaching to address diverse learners' needs spontaneously. These teaching practices provided preservice teachers with solid experience of addressing challenges and obstacles that may enhance preservice teachers' "staying power" [25] to endure within challenging contexts in real classrooms in the future.

The presence of children and museum visitors at Science Circus Days also allowed the preservice teachers to feel a sense of contribution and reward because of the immediate feedback from learners of different ages. Before real teaching practice, preservice teachers usually learn theoretical knowledge about teaching and learning at colleges/universities without having the opportunity to apply their knowledge in teaching practice. As a result, preservice teachers might try to imagine applying their knowledge, might not have opportunities to actually use the knowledge for years, and eventually might forget or lose sight of the knowledge they have learned. In fact, as Skilbeck and Connell [21] assert,

there is widespread criticism of educational courses, notably by students in training, beginning teachers, and school principals. Teachers in their initial years in the profession express frustration over coursework for which they generally perceive little value intellectually or practically. Most find considerable difficulty in explaining the relevance of educational research and theory to their teaching. (p. 12)

The public event of Science Circus Days provided the preservice teachers with opportunities to really implement the theory and knowledge they had learned in courses and interact with learners closely. In fact, being able to integrate theory and practice has been reported by preservice teachers as one of the most important skills they obtained in teacher preparation programs [1]. Importantly, the instant feedback preservice teachers received from visitors allowed the preservice teachers to feel they were contributing something useful to the community. That is, Science Circus Days make preservice teachers' learning process meaningful and make preservice teachers proud of themselves during their college years without having to wait until they become teachers.

Science Circus Days facilitate preservice teachers to develop insights for teaching through feedback, reflection, and observation. Teaching is only valid when learning happens. One might ask, how do I know if my teaching really contributes to students' learning? The feedback from learners, self-reflection on teaching practice, and observations of others' teaching are all great strategies. During Science Circus Days, preservice teachers closely observed others' teaching practices on the spot and learned from each other. After Science Circus Days, the preservice teachers were invited to reflect on their own teaching practices, realize their strengths and weaknesses, and identify areas for improvement. As a result, Science Circus Days also made the preservice teachers realize the importance of informal science education and inspired them to consider incorporating informal science into their future teaching.

\section{REFERENCES}

[1] Allen, J. M., \& Wright, S. E. (2014). Integrating theory and practice in the pre-service teacher education practicum, Teachers and Teaching, 20(2), 136-151. doi: 10.1080/13540602.2013.848568

[2] Anderson, A., Druger, M., James, C., Katz, P., \& Ernisse, J. (2001). An NSTA position statement on informal science education. In P. Katz (Ed.), Community connections for science education (pp. ix-xi). Arlington, VA: NSTA Press.

[3] Avraamidou, L. (2015). Reconceptualizing elementary teacher preparation: A case for informal science education. International Journal of Science Education, 37(1), 108-135. doi: 10.1080/09500693.2014.969358

[4] Aydeniz, M., \& Southerland, S. A. (2012). A national survey of middle and high school science teachers' responses to standardized testing: Is science being devalued in schools? Journal of Science Teacher Education, 23(3), 233-257. doi: 10.1007/s10972-012-9266-3 
[5] Burkman, A. (2012). Preparing novice teachers for success in elementary classrooms through professional development. Delta Kappa Gamma Bulletin, 78(3), 23-33.

[6] Chesebrough, D. (1994). Informal science teacher preparation. Science Education International, 5(2), 28-33.

[7] Clark, S. K. (2012). The plight of the novice teacher. The Clearing House, 85(5), 197-200.

[8] Davis, E. A., Petish, D., \& Smithey, J. (2006). Challenges new science teachers face. Review of Educational Research, 76(4), 607-651. doi: 10.3102/00346543076004607

[9] Ferry, B. (1995). Science centers in Australia provide valuable training for preservice teachers. Journal of Science Education and Technology, 4, 255-260. doi: 10.1007/BF02211840

[10] Flores, M. (2006). Being a novice teacher in two different settings: Struggles, continuities, and discontinuities. Teachers College Record, 108(10), 2021-2052. doi: 10.1111/j.1467-9620.2006.00773.x

[11] Hsu, P.-L., \& Roth, W.-M. (2010). From a sense of stereotypically foreign to belonging in a science community: Ways of experiential descriptions about a high school students' science internship. Research in Science Education, 40, 291-311. doi: 10.1007/s11165-009-9121-5

[12] Ingersoll, R. (2003). Is there really a teacher shortage? Seattle, WA: Center for the Study of Teaching and Policy, University of Washington.

[13] Jung, M. L., \& Tonso, K. L. (2006). Elementary preservice teachers learning to teach science in science museums and nature centers: A novel program's impact on science knowledge, science pedagogy, and confidence teaching. Journal of Elementary Science Education, 18(1), 15-31. doi: 10.1007/BF03170651

[14] Katz, P., McGinnis, J. R., Hestness, E., Riedinger, K., Marbach-Ad, G., Dai, A., \& Pease, R. (2011). Professional identity development of teacher candidates participating in an informal science education internship: A focus on drawings as evidence. International Journal of Science Education, 33, 1169-1197. doi: 10.1080/09500693.2010.489928

[15] Kelly, J. (2000). Rethinking the elementary science methods course: A case for content, pedagogy, and informal science education. International Journal of Science Education, 22(7), 755-777. doi: 10.1080/09500690050044080

[16] Marton, F. (1981). Phenomenography: Describing conceptions of the world around us. Instructional Science, 10(2), 177-200. doi: 10.1007/BF00132516
[17] Olson, L. (2000). Finding and keeping competent teachers. Education Week, 19(18), 12-17.

[18] Rennie, L. J., Feher, E., Dierking, L. D., \& Falk, J. H. (2003) Toward an agenda for advancing research on science learning in out-of-school settings. Journal of Research in Science Teaching, 40(2), 112-120. doi: 10.1002/tea.10067

[19] Rice, D. C., \& Roychoudhury, A. (2003). Preparing more confident preservice elementary science teachers: One elementary science methods teacher's self-study. Journal of Science Teacher Education, 14(2), 97-126. doi: 10.1023/A:1023658028085

[20] Riedinger, K., Marbach-Ad, G., McGinnis, R. J., Hestness, E., \& Pease, R. (2011). Transforming elementary science teacher education by bridging formal and informal science education in an innovative science methods course. Journal of Science Education and Technology, 20(1), 51-64. doi: 10.1007/s10956-010-9233-8

[21] Skilbeck, M., \& Connell, H. (2004). Teachers for the future: The changing nature of society and related issues for the teaching workforce. Canberra, Australia: Ministerial Council on Education, Employment, Training, and Youth Affairs.

[22] Sin, S. (2010). Considerations of quality in phenomenographic research. International Journal of Qualitative Methods, 9(4), 305-319.

[23] Spencer, B. H., Cox-Petersen, A. M., \& Crawford, T. (2005). Assessing the impact of service learning on preservice teachers in an after-school program. Teacher Education Quarterly, 32(4), 119-135.

[24] Stepans, J., \& McCormack, A. (1985). A study of scientific conceptions and attitudes toward science of prospective elementary teachers: A research report. Paper presented at the meeting of the Northern Rocky Mountain Educational Research Association, Jackson Hole, Wyoming. (ERIC Document Reproduction Service No. ED 266 024).

[25] Tricarico, K. M., Jacobs, J., \& Yendol-Hoppey, D. (2015). Reflection on their first five years of teaching: understanding staying and impact power, Teachers and Teaching, 21(3), 237-259. doi: 10.1080/13540602.2014.953821

[26] Wallace, C. S., \& Brooks, L. (2015). Learning to teach elementary science in an experiential informal context: Culture, learning, and identity. Science Education, 99(1), 174-198. doi: $10.1002 /$ sce. 21138

[27] Watkins, P. (2005). The principal's role in attracting, retaining, and developing new teachers. The Clearing House, 79(2), 83-87. doi: 10.3200/TCHS.79.2.83-87 